\title{
Genetic sex Determination supports the Gulf of California AS AN IMPORTANT HABITAT FOR MALE AND FEMALE SPERM WHALES (Physeter macrocephalus)
}

\author{
Nadia T. Rubio-Cisneros ${ }^{1,2,}$, Sarah L. Mesnick ${ }^{2,3}$, Ricardo Vázquez-Juárez ${ }^{1}$, \\ Jorge Urbán Ramírez ${ }^{4}$, Celine A. J. Godard ${ }^{5}$, Roger Payne ${ }^{6}$ and Andrew E. Dizon ${ }^{2}$
}

KEYwords: sperm whale, Physeter macrocephalus, Gulf of California, sex determination, Gulf of California.

In sperm whales, Physeter macrocephalus (Linnaeus, 1758), sexual segregation is evident in both the differential geographic distribution of the sexes and the species' social organization (Rice, 1989). Females and their dependent young are mostly found in tropical and subtropical waters, in which they typically reside in groups of about 20 to 40 individuals (Whitehead et al., 1991a). Subadult males form non-cohesive aggregations (bachelor schools), while adult males tend to be solitary and their range extends into higher latitudes (Best, 1979; Richard, 1995). Adult males also spend periods of time in low latitudes, apparently roving among groups of females in search of mates and sometimes foraging with them (Whitehead, 1993).

Since the $18^{\text {th }}$ century, sperm whales have been opportunistically sighted in the Gulf of California (Townsend, 1935; Vidal et al., 1993). Adult males, groups of subadult males, and groups of females and their dependent young have been recorded there. Their distribution is apparently related to the occurrence of one of their most important prey resources, the jumbo squid, Dosidicus gigas (Townsend, 1935; Leatherwood et al., 1988; Vidal et al., 1993; Jaquet and Gendron, 2002; RuizCooley et al., 2004).

It was not until the last decade, however, that systematic surveys of sperm whales were conducted in these waters (Mangels and Gerrodette, 19947; Gendron, 2000; Jaquet and Gendron, 2002). In these surveys, sex determination was conducted opportunistically by visual observations. While it is generally easy to visually distinguish adult male sperm whales at sea due to their large size and distinct morphology (Best, 1979), it is difficult to reliably distinguish between adult females and non-adult males. Molecular techniques have proved to be an important tool for identifying sex in several cetacean species (Palsbøll et al., 1992; Bérubé and Palsbøll, 1996; Abe et al., 2001; Rosel, 2003; Morin et al., 2005). Here, we report on the use of molecular techniques for the first time to determine the sex of sperm whales in the Gulf of California during fall 1999.

From August to November 1999, Ocean Alliance embarked on a four-month cruise onboard the $R / V$ Odyssey in the Gulf of California, which is part of a 5year worldwide study on pollutants in free ranging sperm whales (Godard et al., 2003 ). During this study, the $R / V$ Odyssey focused search effort over steep-sided basins in the central region of the Gulf of California (Rusnak et al., 1964) which have been shown to be preferred habitat for sperm whales (Jaquet et al., 2002). The $R / V$ Odyssey spent 39 days at sea, observed sperm whales on 30 of these days, and collected tissue samples using a projectile biopsy system on 28 days. In order to minimize potential disturbance to the whales due to close approach of the vessel, the $R / V$ Odyssey has a platform near the bow that projects laterally for eight meters. Biopsy arrows are deployed from this platform so the minimum distance required between vessel and whale can be achieved. Biopsy darts used were $40 \mathrm{~mm}$ long and $8 \mathrm{~mm}$ in diameter. The stainless steel cylindrical punch was washed with soap, sterilized in alcohol and rinsed in de-ionized water before use. Arrows fitted with a compressed foam stopper (Barrett-Lennard et al., 1996) were fired at a range of 10 to $20 \mathrm{~m}$ from a $68 \mathrm{~kg}$ pull, compound crossbow (Barnett RC 150). Biopsy samples were usually collected from the flank of the animal below the dorsal fin, and the region of each dart was recorded. The floating dart was recovered with a dip net.

\footnotetext{
${ }^{1}$ Centro de Investigaciones Biológicas del Noroeste (CIBNOR), La Paz, B.C. S., Mexico, 23090.

${ }^{2}$ Southwest Fisheries Science Center, NOAA Fisheries Service, La Jolla, CA, USA 92037.

${ }^{3}$ Center for Marine Biodiversity and Conservation, Scripps Institution of Oceanography, University of California, San Diego, CA, USA 92093-0203.

${ }^{4}$ Universidad Autónoma de Baja California Sur México, Dep. Biología Marina, La Paz, U.A.B.C.S., Mexico 23081.

${ }^{5}$ The Institute of Environmental and Human Health Texas Tech University and TTU, Health Sciences Center, Lubbock, Texas, USA 79416.

${ }^{6}$ Ocean Alliance, Lincoln, MA, USA 01773.

* Corresponding author: Nadia T. Rubio-Cisneros - Scripps Institution of Oceanography, University of California. San Diego, La Jolla, CA, USA 92037. E-mail: nrubio@ucsd.edu.

${ }^{7}$ Mangels, K. and Gerrodette, T. (1994) Report of cetacean sightings during a marine mammal survey in the eastern Pacific Ocean and the Gulf of California aboard the NOAA ships Mc Arthur and David Starr Jordan, July 28-November 6, 1993. NOAA TM-NMFSSWFSC-211, US Department of Commerce, Seattle, WA, USA.

${ }^{8}$ Godard, C., Clark, R., Harper, C., Mesnick, S., Moore, M., Payne, R., Rubio-Cisneros, N. and Stegeman, J. (2003) CYP1A1 expression in sperm whale Physeter macrocephalus skin biopsies show site but not sex differences. Page 60 in Abstracts, 15th Biennial conference on the Biology of Marine Mammals, 14-19 December, Greensboro, NC, USA.
} 
Skin samples were stored in 20\% dimethyl sulfoxide (DMSO) solution saturated with $\mathrm{NaCl}$ (Amos and Hoelzel, 1991) and then transferred to a $-80^{\circ} \mathrm{C}$ freezer. Genomic DNA was isolated using a salting out method based on a modification described by Aljanabi et al. (1997). Gender was determined using a multiplex polymerase chain reaction (PCR) method (Saiki et al., 1988), modified from Richard et al. (1994), in which both SRY (male determining factor) and keratin (used as positive PCR control) genes were amplified (Table 1). PCR amplifications of biopsy samples from the Gulf of California were performed together with two positive controls of a male and female obtained from stranded sperm whales in which sex was determined by physical examination (Southwest Fisheries Science Center-SWFSC Tissue Archive, La Jolla, CA, USA).

The PCR was performed in a programmable thermal cycler (PTC-100, M J Research, Inc.) with an initial denaturation at $92^{\circ} \mathrm{C}$ for 2 minutes, followed by 45 cycles of $94^{\circ} \mathrm{C}$ for 30 seconds, $58^{\circ} \mathrm{C}$ for 45 seconds, $72^{\circ} \mathrm{C}$ for 45 seconds, and 3 minutes at $72^{\circ} \mathrm{C}$ for final extension. PCR products were loaded on a $2 \%$ agarose gel and electrophoresed at 85 volts for 30 minutes. The keratin product fluoresced under UV light at $\sim 311 \mathrm{bp}$ and the SRY (male) product at $152 \mathrm{bp}$. Thus, males were revealed by two bands on the gel at $\sim 311 \mathrm{bp}$ and $\sim 152 \mathrm{bp}$ and females were identified as one band at $\sim 311 \mathrm{bp}$.

Sperm whales were found around San Pedro Martír Island, in the Guaymas Depression area and along the Carmen and Farallon Depresions (Figure 1). These results are consistent with sperm whale aggregations reported by Jaquet et al. (2002) from May to July of 1998 and 1999 and extend these observations into the late summer and fall, September through November.

Two-hundred sixteen biopsy samples were collected. Of these, 192 successfully amplified for sex determination; 160 samples were determined to be female and 32 were male (Table 2). Sex results were plotted on a bathymetric map using Geographic Information System (GIS) software (Arc View GIS version 3.2). Mixed groups were mainly found in waters where the depth reaches $800-1000 \mathrm{~m}$ followed by waters where the depth reaches $1600-1800 \mathrm{~m}$. Previous work reports that mixed groups usually stay in offshore waters where they feed on meso and bathypelagic squid (Whitehead et al., 1991a; Best, 1999). The adult males in this study were found in water depths ranging from 350 to $1800 \mathrm{~m}$, which is similar to the results of several previous studies (Whitehead et al., 1991b; Scott and Sadove, 1997; Best, 1999). Among the males, five were determined to be adults based on field observations of body size (individuals estimated to be about $13-15 \mathrm{~m}$ in length) following the body size classification scheme proposed by Best (1979) and Whitehead (1993). The remaining males were categorized as "non-adult" and thus included samples taken from all smaller size classes.

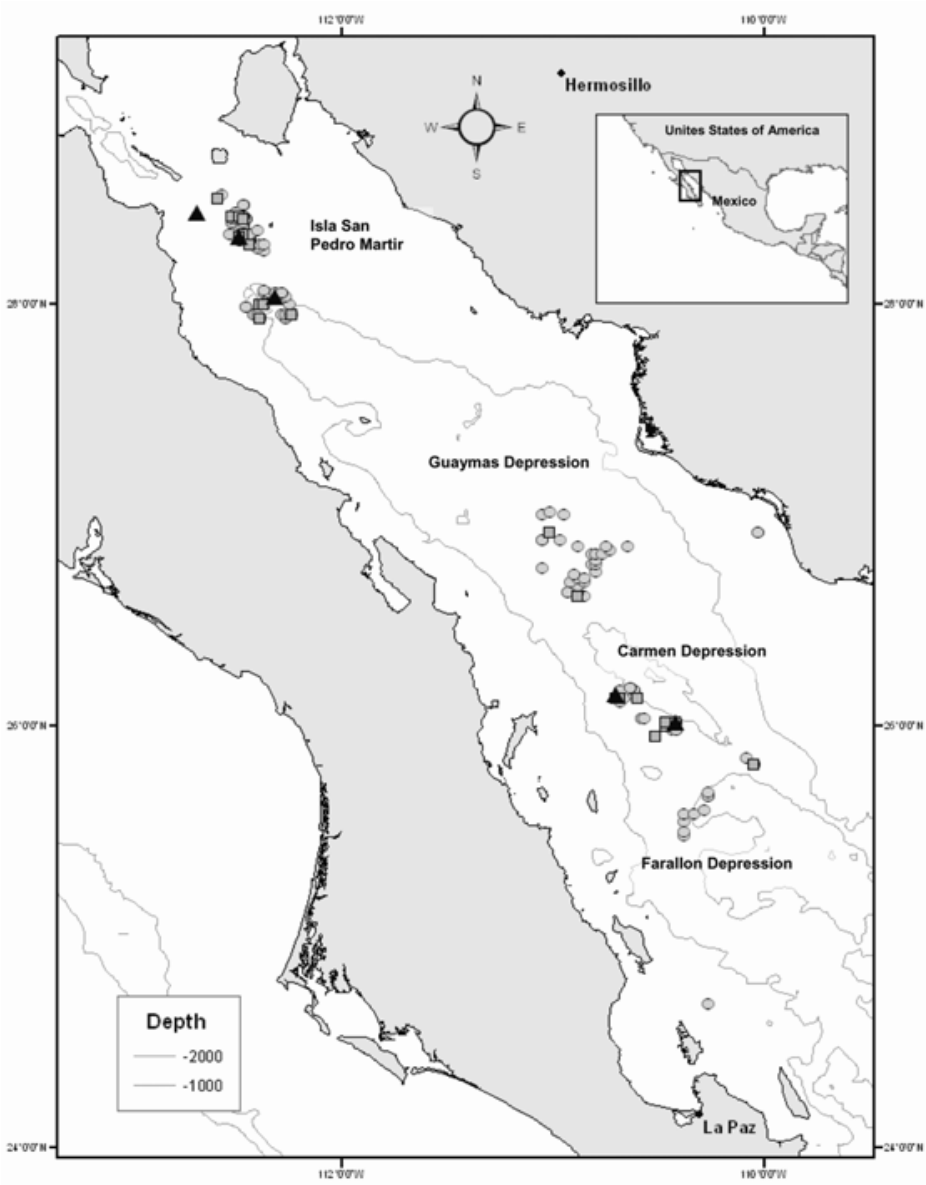

Figure 1. Sperm whales sampled in Gulf of California from August to November 1999. (•) females, $(\square)$ non adult males, $(\mathbf{\Delta})$ adult males, $(\bullet)$ cities.

Table 1. Primers used in the genetic sex determination of Gulf of California sperm whales.

\begin{tabular}{lll}
\hline \hline PRIMER & \multicolumn{1}{c}{ SEQUENCE } & \multicolumn{1}{c}{ REFERENCE } \\
\hline \hline Sry PMF & 5' CATTGTGTGGTCTCGTGATC 3' & Richard et al. (1994) \\
Sry PMR & 5' AGTCTCTGTGCCTCCTCGAA 3' & Richard et al. (1994) \\
KF & 5' AGATCAGGGGTTCATGTTTCTTTGC 3' & J. Hyde, SWFSC, pers. comm. \\
KR & 5' TTTACAGAGGTACCCAAGCCTAAG 3' & J. Hyde, SWFSC, pers. comm. \\
\hline \hline
\end{tabular}


No "bachelor schools" were found. Of the five adult males identified, none were solitary and all were sampled with at least one female and sometimes many more (Table 2). This result combined with field observations of calves and small immature animals swimming together with the sampled animals are consistent with the findings of Jaquet et al. (2003) who suggest that the Gulf of California is likely to be a breeding ground for sperm whales.

Molecular tools have been used to determine the sex of individuals and population identity of a number of large whale species in the Gulf of California (e.g. Bérubé et al., 2002; Croll et al., 2002; Gendron, 2001; Enriquez-Paredes, 2005; Gonzalez-Peral et al., 2006). This information is useful for building a more complete picture of the ecology of wild populations and for determining critical habitat when designing conservation strategies. For example, the genetic distinctiveness of fin whale (Balaenoptera physalus) samples from the Gulf of California led the authors to propose a separate conservation unit with special managements needs (Bérubé et al., 2002). In addition, the merging of genetic, acoustic, and field data on Gulf of California fin whales led Croll et al. (2002) to suggest that this species uses the region as a foraging and display ground. Long-term field surveys of blue whale (Balaenoptera musculus) mother-calf pairs in the Gulf of California support the idea that this area is also a critical nursing and calving habitat for the species and where mating possibly occurs (Gendron, 2001; EnriquezParedes, 2005). The sex, pattern of distribution and high haplotypic genetic diversity among humpback whale (Megaptera novaeangliae) samples in the Gulf of California implies that this region is an important breeding ground for the species in the North Pacific (Gonzalez-Peral et al., 2006).

As a subtropical area with high primary productivity levels (Zeitschel, 1969; Álvarez-Borrego et al., 1991), the Gulf of California supports a diversity of temperate and warm water cetacean species which coexist in this dynamic, rich and productive marginal sea (Urbán, 19939; Alvarez-Borrego, 2002). Previous studies (Bérubé et al., 2002; Croll et al., 2002; Gendron, 2002; Enriquez-Paredes, 2005; Gonzalez-Peral et al., 2006) suggested the Gulf of California is a critical area for large whale conservation. The research presented here is the first effort to apply large scale genetic data from sperm whale samples in the Gulf of California and confirms that this region is an important habitat for male and female sperm whales.

Table 2. Number of sperm whales sampled at the same time and place and the sexes of the individuals sampled together (designated as the number of females/males). Total group size was not noted by $R / V$ Odyssey. $\mathrm{F}=$ female, $\mathrm{M}=$ non-adult male, $\mathrm{MA}=$ adult male.

\begin{tabular}{lcccccccccc}
\hline \hline $\begin{array}{l}\text { NUMBER OF } \\
\begin{array}{l}\text { INDIVIDUALS } \\
\text { SAMPLED TOGETHER }\end{array}\end{array}$ & 2 & 3 & 4 & 5 & 6 & 7 & 8 & 9 & 10 & $>10$ \\
\hline \hline & $2 \mathrm{~F}$ & $3 \mathrm{~F}$ & $4 \mathrm{~F}$ & $5 \mathrm{~F}$ & $5 \mathrm{~F} / 1 \mathrm{M}$ & $6 \mathrm{~F} / 1 \mathrm{M}$ & $8 \mathrm{~F}$ & $5 \mathrm{~F} / 3 \mathrm{M} / 1 \mathrm{MA}$ & $10 \mathrm{~F}$ & $21 \mathrm{~F} / 1 \mathrm{M}$ \\
$\begin{array}{l}\text { Sexes of the } \\
\text { individuals }\end{array}$ & $2 \mathrm{~F}$ & $3 \mathrm{~F}$ & $3 \mathrm{~F} / 1 \mathrm{M}$ & $4 \mathrm{~F} / 1 \mathrm{M}$ & $5 \mathrm{~F} / 1 \mathrm{M}$ & $5 \mathrm{~F} / 2 \mathrm{M}$ & $7 \mathrm{~F} / 1 \mathrm{M}$ & $7 \mathrm{~F} / 1 \mathrm{M} / 1 \mathrm{MA}$ & $11 \mathrm{~F} / 3 \mathrm{M}$ \\
$\begin{array}{l}\text { sampled } \\
\text { together }\end{array}$ & $2 \mathrm{~F}$ & $3 \mathrm{~F}$ & $3 \mathrm{~F} / 1 \mathrm{M}$ & & $4 \mathrm{~F} / 2 \mathrm{M}$ & & $3 \mathrm{~F} / 5 \mathrm{M}$ & & & $8 \mathrm{~F} / 1 \mathrm{MA}$ \\
& $2 \mathrm{~F}$ & & & & & & & & & \\
\hline \hline
\end{tabular}

\section{Acknowledgements}

We are grateful to the Ocean Alliance whose financial support and generous sharing of tissue samples made this research possible. Our thanks also go to the crew of the $R / V$ Odyssey. This research was conducted under permit No 4903 from Mexico's Secretaria de Medio Ambiente Recursos Naturales y Pesca. Samples were exported to the USA under a scientific CITES permit No. 821387. We are grateful for the expertise and financial support of the Molecular Ecology Laboratory at SWFSC, in particular: Phillip Morin, Carrie Le Duc, Kelly Robertson, Aimee Lang, Kelly Coultrup, John Hyde and Janet Lowther. Karen Evans shared the positive control samples of stranded specimens. For assistance with the GIS mapping, we thank Richard Crosgrove (SWFSC). For their special support and encouragement, we thank Lorenzo Rojas Bracho (Instituto Nacional de Ecologia), Iain Kerr, Kim Marshal and Josh Jones (Ocean Alliance), Ira Fogel (CIBNOR) and Sergio Flores, Clara Perez and Maribelle Cruz (UABCS). Carlos Olavarria and an anonymous reviewer provided thoughtful comments on the manuscript.

\section{References}

Abe, H., Goto, M. and Pastene, L. (2001) Practical use of multiplex fluorescent PCR for cetacean sex identification. Marine Mammal Science 17(3): 657-664.

\footnotetext{
${ }^{9}$ Urbán, J. (1993) Los mamíferos marinos del Pacífico Mexicano. Page 50 in Abstracts, V Congreso Latinoamericano de Ciencias del Mar. 27 Sptember-1 October, La Paz, Baja California Sur, México.
} 
Aljanabi, S. And Martinez, I. (1997) Universal and rapid saltextraction of high quality genomic DNA for PCR-based techniques. Nucleic Acid Research 25(22): 4692-4693.

Alvarez-Borrego, S. AND LARA, L. (1991) The physical environment and primary productivity of the Gulf of California. Pages 555567 in Simoneit, B. And. Dauphin, J. (Eds) The Gulf and Peninsular Provinces of the Californias. American Association of Petroleum Geologists. Memoir 47, Tulsa, OK, USA.

Alvarez-Borrego, S. (2002) Physical Oceanography. Pages 41-59 in CASE, T., CODY, M. AND EzCuRRA, E. (Eds) A new Island biogeography of the Sea of Cortes. Oxford University Press. New York, NY, USA.

Amos, W. AND Hoelzel, R. (1991) Long term preservation of whale skin for DNA analysis. Report of the International Whaling Commission (Special Issue) 13: 99-103.

BarRetT-LenNard, L., Smith, T. and Ellis, G. (1996) A cetacean biopsy system using light weight pneumatic darts, and its effect on the behavior of killer whales. Marine Mammal Science 12(1): 14-27.

Bérubé, M. and Palsbøll, P. (1996) Identification of sex in cetaceans by multiplexing with three ZFX and ZFY specific primers. Molecular Ecology 5(2): 283-287.

Bérubé, M., Urbán, J., Dizon, A., Brownell, R. and Palsbøll, P. (2002) Genetic identification of a small and highly isolated population of fin whales (Balaenoptera physalus) in the Sea of Cortez, Mexico. Conservation Genetics 3(2): 183-190.

BEST, P. (1979) Social organization in sperm whales, Physeter macro cephalus. Pages 227-289 in WinN, H.E. AND OlLA, B.C. (Eds) Behavior of Marine Animals. Cetaceans. Plenum Press, New York and London.

BEST, P. (1999) Food and feeding of sperm whales Physeter macrocephalus off the west coast of South Africa. South African Journal of Marine Science 21: 393-413.

Croll, D., Clark, C., Acevedo, A., Tershy, B., Flores, S., Gedamke, J. AND URbÁN, J. (2002) Only male fin whales sing loud songs. Nature 417: 808-809.

ENRíQueZ-PAREDES, L. (2005) Identidad genética de la población de ballena azul (Balaenoptera musculus) en el Pacifico nororiental: agregaciones Mexicanas. Ph.D. Thesis. Universidad Autónoma de Baja California. Ensenada, Baja California Norte, Mexico. 198 pp.

Gendron, D. (2000) Family Physeteridae. Pages 635-637 in ÁlvarezCASTAÑEDA, S.T. AND Patton, J.L. (Eds) Mamíferos del noroeste de México vol. II. Centro de Investigaciones Biológicas del Noroeste, S.C. Mexico.

Gendron, D. (2001) Ecologia poblacional de la ballena azul, Balaenoptera musculus, de la peninsula de Baja California. Ph.D. Thesis. Centro de Investigacion y Educacion Superior de Ensenada CICESE. Ensenada, Baja California Norte, Mexico. 104 pp.

Gonzalez-Peral, U. (2006) Identidad poblacional de las ballenas jorobadas (Megaptera novaeangliae) que se congregan en Baja California Sur. M.Sc. Thesis. Universidad Autónoma de Baja California Sur. La Paz, Baja California Sur, Mexico. 60 pp.

Jaguet, N. and Gendron, D. (2002) Distribution and relative abundance of sperm whales in relation to key environmental features, squid landings and the distribution of other cetacean species. Marine Biology 141(3): 591-610.

Jaguet, N., Gendron, D. and CoAKes, A. (2003) Sperm whales in the Gulf of California: residency, movements, behavior, and the possible influence of variation in food supply. Marine Mammal Science 19(3): 545-562.

Leatherwood, S., Reeves, R., Perrin, W. and Evans, W. (1982) Whales dolphins and porpoises of the Eastern North Pacific and adjacent Arctic waters. A guide to their identification. NOAA

\section{Tehcnical report NMFS Circular 444}

LINNAEUS, C. (1758) Systema naturæ per regna tria naturæ, secundum classes, ordines, genera, species, cum characteribus, differntiis, synonymis, locis. Tomus I. Editio decima, reformata. Impensis Direct. Laurentii Salvii, Holmiæ.Stockholm. 824 pp.

Morin, P., Nestler, A., Rubio-Cisneros, N., Robertson, K., Mesnick, S. (2005) Interfamilial characterization of a region of the ZFX and ZFY genes facilitates sex determination in cetaceans and other mammals. Molecular Ecology 14(10): 3275-3286.

Palsbøll, P., Vader, A., Bakke, I. and Elgewely, M. (1992) Determination of gender in cetaceans by the Polymerase ChainReaction. Canadian Journal of Zoology 70(12): 2166-2170.

Rosel, P. (2003) PCR-based sex determination in odontocete cetaceans. Conservation.

Rice, D. (1989) Sperm whales (Physeter macrocephalus). River dolphins and the larger toothed whales. Pages 177-233 in RIDGEWAY, S.H. AND HarRison, R. (Eds) . Handbook of Marine Mammals. Volume4. Academic Press. London, United Kingdom.

RichARD, K., Mc CARRY, S. AND WRIGHY, L. (1994) DNA sequence from the SRY gene of the sperm whale (Physeter macrocephalus) for use in molecular sexing. Canadian Journal of Zoology 72(5): 873-877.

RichARD, K. (1995) A molecular genetic analysis of kinship in free living groups of sperm whales. Ph.D. Thesis. Dalhousie University, Halifax, NS, Canada. 108 pp.

Ruiz-Cooley, I., Gendron, D., Aguíñiga, S., Mesnick, S. And CarriQuiry, J.D. (2004) Trophic relationships between sperm whales and jumbo squid using stable isotopes of $\mathrm{C}$ and N. Marine Ecology Progress Series 277: 275-283.

Rusnak, A., Fisher, R., And Shepard, F. (1964) Submarine Topography of the Gulf of Claifornia (Chart). Page 67 in Marine Geology of the Gulf of California. Memoir 3, American Association of Petroleum Geologists, Tulsa, OK, USA.

Saiki, R., Gelfand, D., Stoffel, S., Scharf, S., Higuchi, R., Horn, G., Mullis, K. And ERlich, H. (1988) Primer-Directed Enzymatic Amplification of DNA with a Thermostable DNA-Polymerase. Science 239(4839): 487-491.

ScotT, T.M. And SAdove, S. (1997) Sperm whale Physeter macrocephalus sightings in the shallow shelf waters of Long Island, New York. Marine Mammal Science 13(2): 317-321.

TownSEND, C. (1935) The distribution of certain whales as shown by the logbook records of American whale ships. Zoologica 19: 1-50.

Vidal, O., Findley, L. And Leatherwood, S. (1993) Annotated checklist of the marine mammals of the Gulf of California Proceedings of the San Diego Society of Natural History 28: 1-16.

Whitehead, H., Waters, S. and Lyrholm, T. (1991a) Social organization of female sperm whales and their offspring: constant companions and casual acquaintances. Behavioral Ecology and Sociobiology 29(5): 385-389.

Whitehead, H., Brenan, S. AND Grover, D. (1991b) Distribution and behavior of male sperm whales on the Scotian Shelf , Canada. Canadian Journal of Zoology 70(5): 912-918.

WHITEHEAD, H. (1993) The behavior of mature male sperm whales on the Galápagos Islands breeding grounds. Canadian Journal of Zoology 71(4): 689-699.

Zeitschel, B. (1969) Primary productivity in the Gulf of California. Marine Biology 3(3): 201-207.

Received 18 July 2006. Accepted 1 December 2006. 